\title{
The Impact of Managers' Personal Values on their Behavior: Evidence from Austria and Slovenia
}

\begin{abstract}
This paper examines the impact of managers' personal values on their behavior in two neighborhood countries: a German speaking free-market economy with long tradition - Austria, and Slovenia - former transition country, with historically very specific collectivistic system. Results are reported for 208 managers from Slovenian and 196 from Austrian organizations.
\end{abstract}

Keywords: Austria, behavior, management, personal values, Slovenia.

Straipsnyje nagrinejjama vadovų asmeninių vertybių įtaka jų elgsenai dvejose kaimyninėse šalyse - Austrijoje, vokiškai kalbanti šalis, kur laisvoji rinka turi gilias tradicijas bei Slovenijoje - neseniai perẻjimo laikotarpi išgyvenusi šalis, kurioje egzistuoja istoriškai specifine kolektyvinè sistema. Tyrimo rezultatai skelbiami apklausus 208 vadovus iš Slovenijos ir 196 vadovus iš ịvairių Austrijos organizacijų.

Raktiniai žodžiai: Austrija, elgsena, valdymas, asmeninės vertybės, Slovėnija.

\section{Introduction}

Management behavior in organizations is dependent upon synergetic set of "hard and soft factors" (Hage, Dewar, 1973; England, 1976; Hambrick, Mason, 1984; Posner, 2010; Nedelko, Mayrhofer, 2012). In frame of examining the impact of soft factors on management behavior, the most important role is attributed to the personal values (Posner, Munson, 1979; Ralston et al., 1993; Connor, Becker, 1994; Ralston et al., 2006; Reynaud et al., 2007). Based on increasing number of empirical studies, management personal values are recognized as an important driver of management behavior in organizations (England, 1976; Finkelstein, Hambrick, 1996; Lang et al., 2000; Hughes et al., 2009; Nedelko, Mayrhofer, 2012).

The role and importance of personal values in management is relatively well covered in the literature, especially cognitions based on studies from well developed economies (Egri, Herman, 2000; Sarros, Santora, 2001; Hood, 2003; Posner, 2010). Significantly less exist empirical surveys examining the role and importance of management values in specific conditions,

Zlatko NEDELKO - assistant professor, Ph.D.; management / business administration; University of Maribor, Faculty of Economics and Business, assistant professor, Razlagova 14, 2000 Maribor, Slovenia. Tel.: 0038622290 131, fax 0038622516 681. E-mail: zlatko.nedelko@uni-mb.si. Scientific research areas: management, organization, leadership, business ethics, personal values, environmental issues, innovativeness. 
where management is confronted with radical political, social, and economic changes (Ardichvili, Kuchinke, 2002; Kozminski, 2008; Nedelko, 2011). Furthermore, existing studies examine the impact of managers' personal values on their behavior mainly in the major players and those Central and East European (CEE) countries, previously having typical socialist system, like former Soviet Union, Poland (Kornai, 1992; Harvie, 1999; Djankov, Murrell, 2002; Kozminski, 2008). On the other hand, little economies or those not in the broad interest are less covered in the literature, like Slovenia (Lang et al., 2000; Kovač et al., 2004; Potočan, Mulej, 2007).

From the view point of Slovenia, which had been a part of former Yugoslavia, had a unique type of socialism, so called "selfmanagement", which differs from typical soviet type of socialism (Černe, 1989; Mrak et al., 2004). Social system in Yugoslavia combined selected characteristics of centrally-planned systems and those from free-market economy (Mrak et al., 2004; Marangos, 2005), due to the links with western economies, eastern economies, as well as being part of Third world countries.

In terms of management practices and behavior it is evident that unique system of self-management in Yugoslavia is reflected in some distinguishing characteristics of management behavior, in comparison to behavior in typical socialistic counties (e.g. Poland, Soviet Union) (Kornai, 1992; Lang et al., 2000; Kozminski, 2008; Nedelko, 2011); as well as to management practices in western economies (House et al., 2004; Brodbeck et al., 2000; Hood, 2003; Posner, 2010).

This paper makes an original and scientific contribution to the literature. First, a comprehensive study of the impact of managers' personal values on their behavior in Slovenia and Austria is done. Values are measured using Schwartz values list (Schwartz, 1992), while managers' behavior is considered as a continuum ranging from autocratic to democratic as proposed by R. Tannenbaum and W. Schmidt (1973). Such combination has not been previously examined in literature. Second, the paper compares the impact of managers' personal values on their behavior in two countries, having different economic / social / cultural development paths; a country with long tradition of freemarket economy - Austria and a former transition country - Slovenia. Compared countries have some historical links and close economic relations nowadays, as well as have some differences in peoples' value orientations (Hofstede, 1980; Ralston et al., 2011). Third, association between personal values and management behavior is examined in successor country of former Yugoslavia - Slovenia, previously having unique self-management system, with some unique characteristics of management behavior. A comparative study, using above mentioned concepts in two compared countries, has not been previously done in the literature.

\section{Literature review and hypotheses development}

\section{Centrally planned vs. free market economies}

After Second World War capitalism and socialism were two dominant and competitive political, social and economic ideologies. Nowadays capitalism is definitive prevalent social and economic system 
worldwide, while only some countries with socialistic system remain. Capitalism put in the forefront achieving self-interests, while socialism those of all members of society or group (Aslund, 1994).

Capitalism was developed on the principles of free-market and taking into account important economic principles (McEwan, 2001), such as: (1) private ownerships, (2) primary role of consumer, and (3) individual benefits for producers. Capitalism is prevalent global social and economic system, despite criticism which sees socialism as an adequate alternative to capitalism (Marx, Engels, 2008).

The importance of socialistic system, as an alternative to capitalism, had risen from 1917 until early 1950s, when CEE countries had adopted it (McEwan, 2001; Potočan, Mulej, 2007). Typical socialistic system had developed in Soviet Union and majority of other CEE countries (Kornai, 1992; Harvie, 1999).

Socialistic systems in CEE countries, as well as in Yugoslavia, had faced with numerous problems (Ericson, 1991). At the end of 1980s or early 1990s, centrally-planned systems collapsed as a consequence of various political, economic, and social factors. These circumstances represent a base for starting transition process (Harvie, 1999; McEwan, 2001; Marangos, 2005).

Transition includes a plethora of political, economic, institutional, structural and behavioral changes, which influence on changing existing principles of national economy and all its entities, with aim of establishing free-market economy (Fischer, Gelb, 1991; De Melo et al., 1996; Campos, Coricelli, 2002; Kozminski, 2008). In terms of content, transition means abandoning self-management practices and adopting well established principles of free-market economy.
A unique variant of socialist system in Yugoslavia, self-management, had it applications also in management and leading processes in state-owned enterprises, representing a distinguished management system, not known before or outside Yugoslavia. The most distinguishing characteristic of organizations in former Yugoslavia was its systems of "self-management". The main idea was to give "companies to employees", thus that employees manage the organizations on their own (Potocan, Mulej, 2007; Nedelko, 2011).

\section{Management behavior}

In this section we highlight the main differences in management behavior in organizations operating in capitalistic freemarket economy and those in former Yugoslavia having previously unique system of self-management. The main duty of management in modern organizations is to adjust organization's working and behavior to the new conditions. Management actions depend upon different goals, like surviving, future development, increasing competitiveness, care for customers, etc. (Daft, 2000; Certo, Certo, 2009).

In line with aims of this paper we are interested in management behavior in organizations, operating in significantly different conditions. On one hand we have management practice in organizations formerly having unique system of selfmanagement, while on the other hand management behavior in well-developed western economies.

With transition into free-market economy the role of management changed radically, for those having unique system of management behavior. When assessing the development of new management practices and actual state of management 
behavior in former transition economies, elements of former socialistic system coupled with self-management practices, should be considered, since their impact is still present.

This is especially important for management which was active in state organizations in centrally planned economy, where an emphasis on self-management system was present. The role of management in such circumstances was rather limited, especially on the execution of centrally planned task and goals, which were agreed upon based on social and economic goals of socialistic system (Newman, Nollen, 1998; Ardichvili, Gasparishvili, 2001; Uhlenbruck et al., 2003; Nedelko, 2011).

Transition of organizations, in the framework of national transition process, defined a new role of management in those economies. Changed role of management in organizations consequently also required radical change of management behavior, especially on these areas (Zahra et al., 2000; Nedelko, 2011):

- management plan and execute strategies based on analysis of organizational environment and conditions;

- management defines organizational goals based on interests of key stakeholders, especially owners;

- management decides about supply, disposing and use of organizational material, human, and financial resources;

- management decides about products / services assortment of organization, which is at the moment most suitable;

- management is responsible to the ow• ners;

- management payments and rewards are dependent upon organizational success;

- management accepts risks and encourage innovativeness in organization;
- management use especially expert and personal power for influencing others.

Development of desired management behavior in frame of organizations transition process was influenced by (Megginson et al., 1992; Peng, Heath, 1996; Daft, 2000; Potočan, Mulej, 2007; Schermerhorn, 2008):

- conditions, like availability of capital, lack of competitors;

aims and goals of organization;

- characteristics of organization, e.g. organizational structure;

- subjective characteristics of managements, e.g. personality, values, culture;

- power and influence of management in comparison to the owners;

- development of social-economic framework for organizations;

- capacities and skills of management for organizational transformation.

Due to the new tasks, management must also gain new knowledge or upgrade existing, which enable managers to manage organizations in changed circumstances. Thus, key knowledge and skills are (Newman, Nollen, 1998; Uhlenbruck et al., 2003):

- strategic thinking and planning,

- willingness to take risks, leading and executing needed changes in organizations,

- ability to understand the need for optimization of business processes, striving toward optimizing performance,

- technical knowledge, related to quality insurance,

- systemic knowledge, knowledge about working with human resources.

Next we examine one among most important soft factors that drives management behavior, namely personal values. 


\section{The role of personal values} for management behavior

The first studies considering the impact of managers' values on their behavior emerged in second half of $20^{\text {th }}$ century, within industrial psychology, management and organization (England, 1967; Posner, Munson, 1979; Peters, Waterman, 1982). The main predisposition of all examinations was that managers' values are one among key drivers of management behavior in modern organizations (Kovač et al., 2004; Hughes et al., 2009).

In that framework values influence on managers' perception of situations and problems, nature of the decisions, shaping the relationship between management and staff, perception of ethical dilemmas, and perception of organizational success (England, 1976).

Management authors deal with the role of personal values in / for management behavior in various ways. This means, that various different concepts for measuring values and management behavior are utilized. For instance, in terms of management values, England developed questionnaire for measuring personal values of management (England, 1967).

Besides specially developed questionnaires for examining managers' personal values, mainly widely known questionnaire from psychological literature are used. Most frequently are used Rokeach values survey (Rokeach, 1973), Hofstede's cultural dimensions (Hofstede, 1980), and Schwartz value survey (Schwartz, 1992).

On the other hand management behavior is most frequently measured with use of the transactional-transformational leadership theory (Burns, 1978; Bass, Avolio, 1990), charismatic leadership (Sosik, 2005).
In terms of combinations, most frequently are used combinations of well known management behavior cognitions from transactional-transformational leadership theory (Bass, Avolio, 1990) and Schwartz Values survey (Egr, Herman, 2000; Sarros, Santora, 2001; Giberson et al., 2009). On the other hand, a worldwide research of leadership practices is done in framework of GLOBE program, which defines typical characteristics of management in different cultural environments (House et al., 2004).

Evident is that majority of predispositions about the association between management personal values and its behavior are based upon management behavior in well-developed western economies. In that framework it would be interesting to examine association between management personal values and its behavior in a county, having previously unique system of self-management.

Based on above outlined cognitions about management behavior in different environment, i.e., differences in management behavior in organizations operating in former transitions economies and welldeveloped economies, we postulated two general hypotheses:

H 1: Management behavior in Slovenia and Austria is different.

$H$ 2: Different personal values drive management behavior in Slovenia and Austria.

\section{Methods}

\section{Sample and procedure}

Sampling was done based on GVIN directory which lists Slovenian organizations and Aurelis which lists Austrian. Sampling 
was done according to the data in NACE classification for both countries. Organizations having more than 50 employees were included in sample. All managers participated voluntarily in the survey.

In Slovenia, survey was done using Computer assisted telephone interviewing. Altogether 700 managers at different position in sampled organization were contacted via telephone, while 208 answers were obtained, appropriate for our research, resulting in $29.7 \%$ response rate. In Austria, an online survey was done. Has been sent the link to the questionnaire to approximately 2400 managers at various hierarchical positions. Altogether we received 215, while 196 answers were used in analysis, resulting in $8.2 \%$ response rate. Demographic characteristics for both samples are outlined in Table 1.

\section{Measures}

Personal values. Managers' personal values were measured using Schwartz Value Survey (SVS) (Schwartz, 1992). SVS includes a list of 56 personal values, aimed to measure 10 motivational types (for people behavior). Respondents in the survey rate each of 56 personal values using a 9-point Likert-type scale, ranging from "opposed to my values" (-1) to "of

Demographic characteristics for Austrian and Slovenian sample

\begin{tabular}{|l|c|c|}
\hline \multicolumn{1}{|c|}{ Variable } & Austria & Slovenia \\
\hline Age & 45.66 years & 47.28 years \\
\hline Age - grouped & & \\
Less than 35 years & $18.4 \%$ & $18.8 \%$ \\
36 - 45 years & $28.9 \%$ & $22.6 \%$ \\
46 - 55 years & $36.3 \%$ & $39.4 \%$ \\
More than 55 years & $16.3 \%$ & $19.2 \%$ \\
\hline Gender & & \\
Male & $78.4 \%$ & $51.0 \%$ \\
Female & $21.6 \%$ & $49.0 \%$ \\
\hline Education & & \\
Finished secondary school & $37.9 \%$ & $25.1 \%$ \\
Finished bachelor, master or doctorate degree & $62.1 \%$ & $74.9 \%$ \\
\hline Position in organization & & \\
First-level manager & $11.5 \%$ & $2.9 \%$ \\
Mid-level manager & $37.9 \%$ & $26.0 \%$ \\
Upper-level manager & $50.5 \%$ & $71.2 \%$ \\
\hline Working experiences & 25.24 years & 23.52 years \\
\hline Working experiences - grouped & & \\
Less than 10 years & $10.0 \%$ & $14.9 \%$ \\
10 - 20 years & $30.5 \%$ & $21.6 \%$ \\
20 - 30 years & $36.8 \%$ & $35.1 \%$ \\
More than 30 years & $22.6 \%$ & $28.4 \%$ \\
\hline Organization size & $11.6 \%$ & \\
Fewer than 49 employees & $48.1 \%$ & - \\
50 to 249 employees & $40.2 \%$ & $6.7 \%$ \\
More than 250 employees & & \\
\hline
\end{tabular}


supreme importance" (7). Groups of values are in proposed research model considered as latent variables, while single values are their indicators. In parentheses Cronbachs' alpha coefficients are outlined. Those groups of values are, power $(\alpha=.694)$, achievement $(\alpha=.794)$, hedonism $(\alpha=.797)$, stimulation $(\alpha=.544)$, self-direction ( $\alpha=.623$ ), universalism $(\alpha=.837)$, benevolence $(\alpha=.735)$, security $(\alpha=.640)$, tradition $(\alpha=.539)$, and conformity $(\alpha=.631)$.

In empirical researching personal values in management studies, authors report similar reliability coefficients. J. C. Sarros and J. C. Santora (2001) report lowest coefficients for conformity (.45) and tradition (.60), while C. P. Egri and S. Herman (2000) for tradition (.46) and security (.64). Tradition yield lowest reliability coefficients, as well is studies of J. C. Sarros and J. C. Santora (2001) (.60) and especially by those of C. P. Egri and S. Herman (2000) (.46). Turning to stimulation, studies of J. C. Sarros and J. C. Santora (2001) and C. P. Egri and S. Herman (2000) report its reliability above .70 .

Management behavior. In our exploratory research, management behavior is considered as multidimensional construct. Each item is framed on the continuum, ranging from autocratic to democratic management. All items are measured using an 8-point Likert-type scale, with anchors referring to autocratic and democratic management behavior.

Based on exploratory factorial analysis of 15 items and reliability analyses, we select eight items that in reliable manner represent management behavior, framed on leadership continuum. Those characteristics are: (1) coordination of work in organization is based more on ( 1 - formal rules and procedures; 8 - informal rules and procedures); (2) working of management is more ( 1 - centralized, 8 - decentralized); (3) management is focused on (1 - goal attainment; 8 - employees and their needs); (4) control process in organization is mainly in domain of (1 - manager/s or superior; 8 - employees), (5) authority in organization ( 1 - has management; 8 - is delegated to the employees); (6) management in organization rely mainly on (1 - positional power; 8 - personal power); (7) cooperation between management and employees is ( 1 - weak; 8 - strong); and (8) cooperation between management and employees is more ( 1 - formal; 8 - informal). Cronbach alpha for the construct was .707.

Regarding exploratory nature of the study, reliability coefficient is acceptable. Comparing to other studies in this field, most of them are confirmatory in their nature, since they use established and previously validated instruments. J. C. Sarros and J. C. Santora (2001) in their study, use transformational-transactional typology, reporting coefficients ranging between .60 and .83. J. J. Sosik (2005) in study of charismatic leadership reports coefficients ranging between .74 and .80 .

Research design. In line with aims of our paper we examine the impact of individual level sub-dimensions of personal values, as clustered by Schwartz values survey (Schwartz, 1992) and its later repetitions (Nedelko, 2011; Ralston et al., 2011), on preferred management behavior. A research model is depicted in Figure 1.

The impact of individual level subdimensions of personal values, as categorized by S. H. Schwartz (1992) was tested using hierarchical regression analysis. The impact was controlled with basic demographic and organizational variables. 


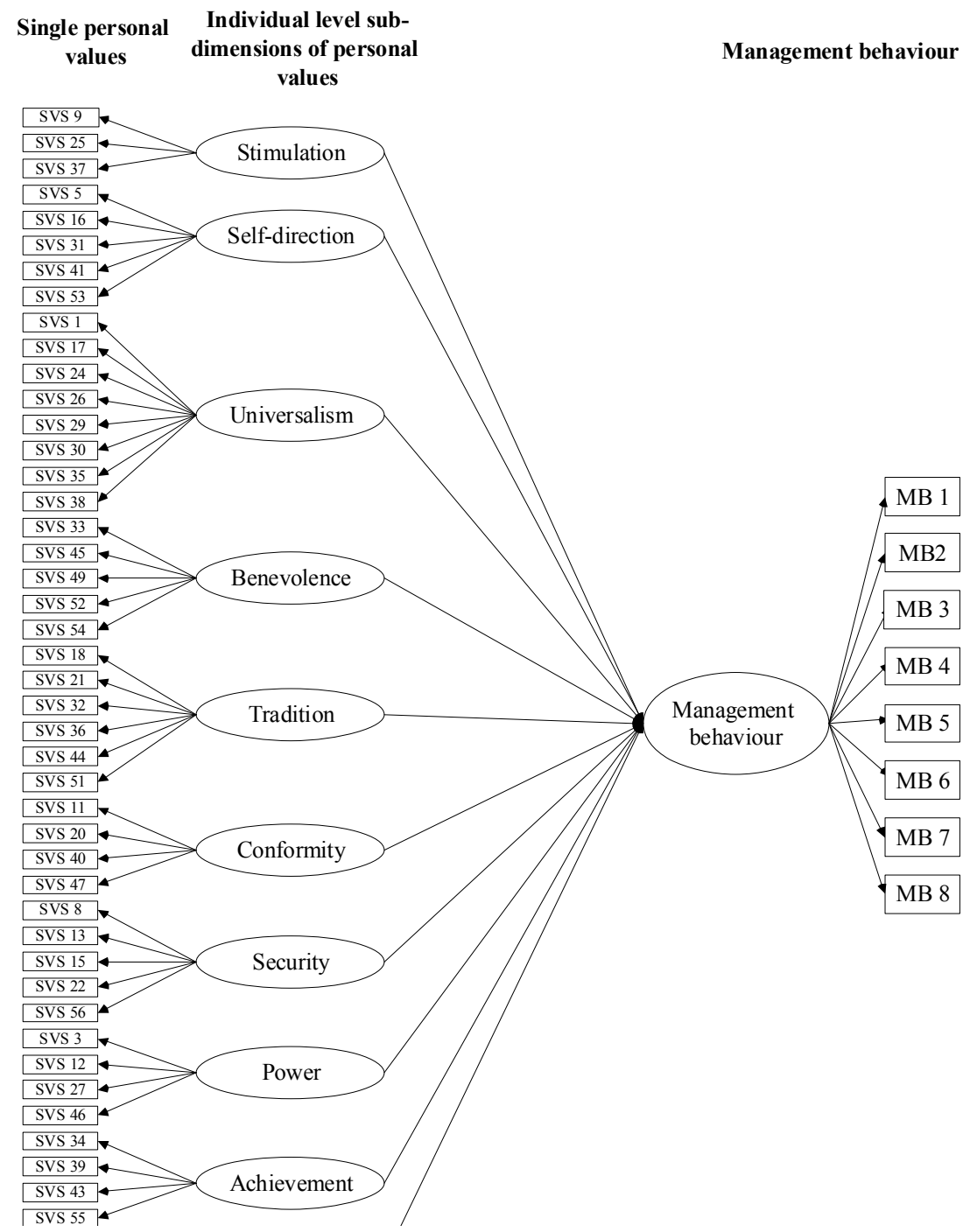

Fig. 1. Research model

\section{Results}

\section{Correlations}

Correlations between basic demographic and organizational variables, sub-dimensions of personal values, and management behavior, reveals that personal values are associated with management behavior. Furthermore, demographic and organizational variables have some mediating role on association between personal values and management behavior. Means, standard deviations, correlations, and reliabilities for the variables of interest in the study are outlined in Table 2. 
THE IMPACT OF MANAGERS' PERSONAL VALUES

$\frac{\widetilde{v}}{\frac{\mathbb{v}}{\sim}}$

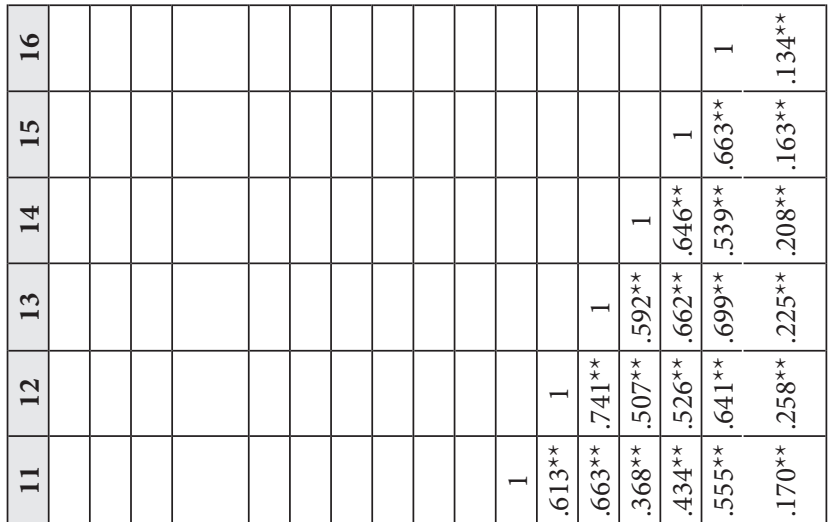

을

은

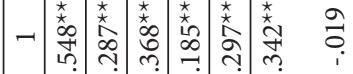

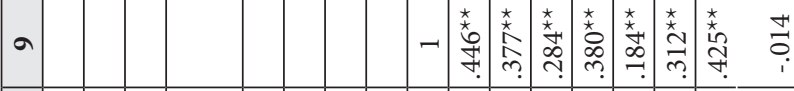

$\infty$

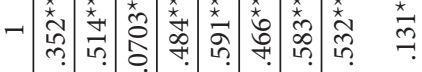

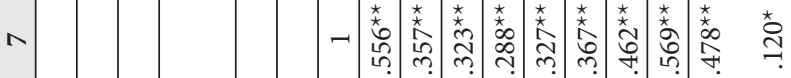

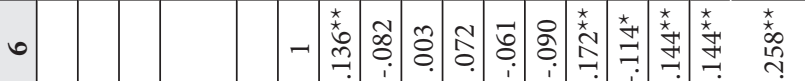

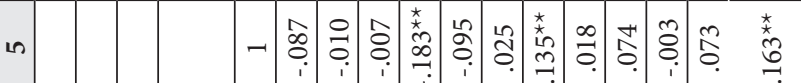

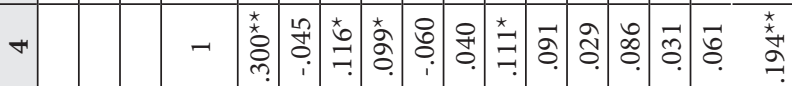

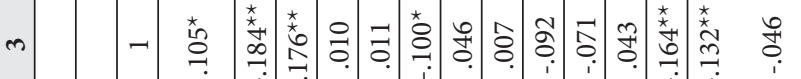

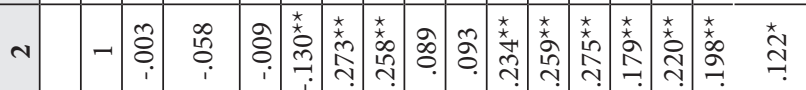

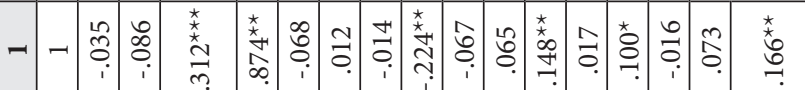

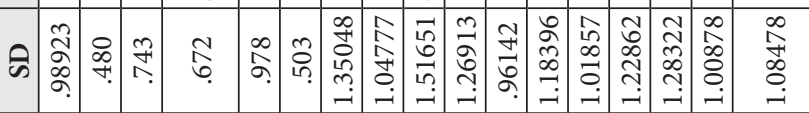

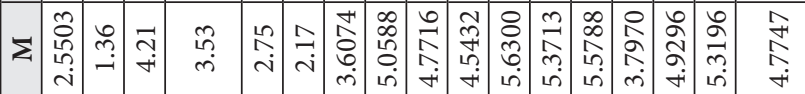

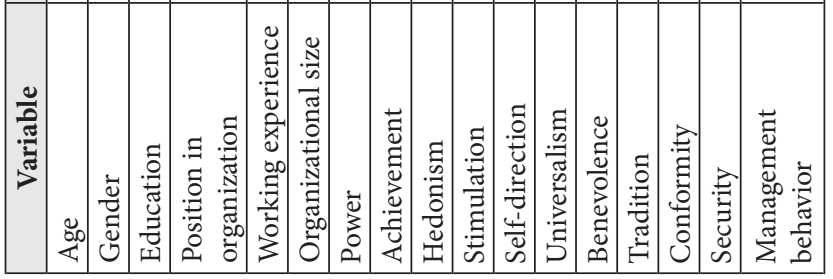

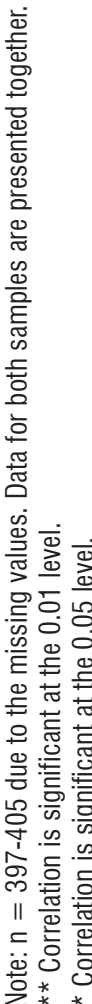


These findings suggest a deeper examination the association between managers' personal values and their behavior, while also controlling the impact with basic demographic and organizational variables. Results for both countries are presented separately.

\section{Management behavior in Slovenia and Austria}

Mean values and ANOVA results for selected items referring to management behavior are outlined in Table 3.

Results reveal differences in management behavior among Slovenian and Austrian managers. Greatest differences are attributed to the distribution of authority among managers and employees in organization, power that managers use to influence others, and management definition of rules and procedures for work in organizations. These findings support hypothesis 1 .

\section{The impact of ten individual level sub-dimensions of personal values on management behavior in Slovenia and Austria}

Model 1 presents enter of chosen set of basic demographic and organizational variables, followed by the ten individual level sub-dimensions of personal values (Model 2). For Slovenian sample the results show that Model 1 (demographic and organizational variables) accounted for $11.3 \%$ of the variance in managers' behavior. Entry of ten groups of personal values (Model 2) increased explained variance in managers' behavior by $14.6 \%$ to a total of $25.9 \%$. ANOVA results reveal that entry of demographic and organizational variables (Model 1) yielded a significant influence on managers' behavior, $\mathrm{F}(6.201)=4.287$, $\mathrm{p}<0.001$. Addition of ten groups of manager values (Model 2) outlined their significant association with managers' behavior, $\mathrm{F}(16.191)=4.183, \mathrm{p}<0.001$.

\section{Management behavior in Slovenia and Austria}

Table 3

\begin{tabular}{|c|c|c|c|c|}
\hline Management behavior & Slovenia & Austria & $\mathbf{F}$ & Sig. \\
\hline $\begin{array}{l}\text { Coordination of work in organization is based more on } \\
\text { ( } 1-\text { formal rules and procedures; } 8 \text { - informal rules and procedures) }\end{array}$ & 5.90 & 4.65 & 52.697 & .000 \\
\hline $\begin{array}{l}\text { Working of management is more } \\
\text { (1 - centralized, } 8 \text { - decentralized) }\end{array}$ & 4.31 & 3.84 & 5.031 & .025 \\
\hline $\begin{array}{l}\text { Management is focused on } \\
\text { (1-goal attainment; } 8 \text { - employees and their needs) }\end{array}$ & 3.45 & 3.89 & 7.490 & .006 \\
\hline $\begin{array}{l}\text { Control process in organization is mainly in domain of } \\
\text { (1- manager/s or superior; } 8 \text { - employees) }\end{array}$ & 4.16 & 3.90 & 2.033 & .155 \\
\hline $\begin{array}{l}\text { Authority in organization } \\
\text { ( } 1 \text { - has management; } 8 \text { - is delegated to the employees) }\end{array}$ & 5.20 & 3.23 & 110.884 & .000 \\
\hline $\begin{array}{l}\text { Management in organization rely mainly on } \\
\text { (1- positional power; } 8 \text { - personal power) }\end{array}$ & 6.22 & 4.51 & 85.940 & .000 \\
\hline $\begin{array}{l}\text { Cooperation between management and employees is } \\
\text { (1- weak; } 8 \text { - strong) }\end{array}$ & 6.10 & 5.63 & 8.161 & .005 \\
\hline $\begin{array}{l}\text { Cooperation between management and employees is more } \\
(1-\text { formal; } 8 \text { - informal })\end{array}$ & 6.12 & 5.10 & 37.579 & .000 \\
\hline
\end{tabular}


Turning to Austria sample, results reveal that demographic and organizational variables explain $7.1 \%$ of the variance in managers' behavior. Entry of ten groups of personal values increased explained variance by $7.8 \%$, to a total of $14.9 \%$. ANOVA results reveal that entry of demographic and organizational variables yielded a significant influence on managers' behavior, $\mathrm{F}(6.182)=2.334$, $\mathrm{p}<0.05$. Addition of ten individual level groups of values (Model 2) outlined their significant association with managers' behavior, $\mathrm{F}(16.172)=1.885$, $\mathrm{p}<0.05$.

Table 4 outlines detailed results of hierarchical regression analysis of individual level sub-dimensions of managers' personal values on their behavior, controlled by basic demographic and organizational variables in Slovenia and Austria.
Standardized regression coefficients reveal that power negatively, while benevolence positively and significantly influence managers' behavior in Slovenia. Thus, heightening importance of power values results in more autocratic management behavior $(\beta=-0.237$; $p<0.05)$, while higher importance of benevolence values results in more democratic management behavior $(\beta=0.221 ; \mathrm{p}<0.05)$. In Austria only power values negatively and significantly influence manager behavior $(\beta=-0.189 ; \mathrm{p}<0.05)$, indicating that with higher importance of those values, management behavior is more autocratic. These findings support hypothesis 2 .

Among demographic and organizational variables, in Slovenia managers' position in organization is significant predictor of their behavior $(\beta=0.168, \mathrm{p}<0.05)$. Thus, managers at hierarchically higher

Regression analysis of managers' personal values on their behavior in Slovenia and Austria

\begin{tabular}{|c|c|c|c|c|c|c|c|c|}
\hline \multirow[t]{2}{*}{ Model } & \multicolumn{2}{|c|}{ R Square } & \multicolumn{2}{|c|}{$\beta$} & \multicolumn{2}{|c|}{$t$} & \multicolumn{2}{|c|}{ Sig. } \\
\hline & Slo & Aut & Slo & Aut & Slo & Aut & Slo & Aut \\
\hline 1.Demographic variables & 0.113 & .071 & & & & & & \\
\hline Age & & & -.145 & .183 & -.960 & 1.302 & .339 & .195 \\
\hline Gender & & & -.070 & .010 & -1.019 & .124 & .310 & .902 \\
\hline Education & & & .009 & -.069 & .144 & -.824 & .885 & .411 \\
\hline Position in organization & & & .168 & .008 & 2.474 & .099 & .014 & .921 \\
\hline Working experience & & & .242 & -.115 & 1.638 & -.802 & .103 & .424 \\
\hline Organizational size & & & -.120 & -.230 & -1.808 & -3.074 & .072 & .002 \\
\hline 2. Personal values & 0.259 & 0.149 & & & & & & \\
\hline Power & & & -.237 & -.189 & -2.640 & -1.997 & .009 & .047 \\
\hline Achievement & & & .020 & -.026 & .202 & -.228 & .840 & .820 \\
\hline Hedonism & & & .028 & -.013 & .341 & -.143 & .733 & .887 \\
\hline Stimulation & & & -.002 & -.023 & -.025 & -.234 & .980 & .816 \\
\hline Self-direction & & & .130 & .064 & 1.294 & .456 & .197 & .649 \\
\hline Universalism & & & .136 & .143 & 1.387 & 1.260 & .167 & .210 \\
\hline Benevolence & & & .221 & -.127 & 2.188 & -.874 & .030 & .383 \\
\hline Tradition & & & .041 & .123 & .473 & 1.247 & .637 & .214 \\
\hline Conformity & & & -.059 & -.002 & -.601 & -.015 & .549 & .988 \\
\hline Security & & & .027 & -.171 & .285 & -1.463 & .776 & .145 \\
\hline
\end{tabular}


positions demonstrate more democratic behavior, than those at lower levels. In Austria organizational size is significant predictor of their behavior $(\beta=-0.230$; $\mathrm{p}<$ $0.05)$, indicating that with increasing the organizational size, management behavior is more autocratic in their nature.

\section{Discussion}

The main contribution of this paper is a comparison of the role of personal values for management behavior in German speaking free-market economy with long tradition - Austria, and former transition country, with historically very specific collectivistic system - Slovenia, previously not done in the literature.

Management behavior in Slovenia and Austria differs. Based on above outlined empirical results we can summarize that Austrian managers are on average more autocratic in their behavior than their Slovenian counterparts.

Having concentration of authority in organizations mostly in hands of managers in Austria reflects Austrian cultural orientation toward having power and authority over others and events (Ralston et al., 2011). High importance of authority for managers is reflected also in more centralized management behavior and consequently organization. Furthermore, this tendency is also reflected in management tendency to rely more on positional power than personal power. Next, management in Austria rather coordinates work of organization with use of more formal rules and procedures than Slovenians. Due to the keeping power for themselves, centralized organization, more formal rules and procedures, positional power, also the cooperation between management and employees in organizations is weaker and more formal than for Slovenian managers.

On the other hand, prevalent management behavior in Slovenian organizations reflects more democratic behavior than those of Austrian counterparts. In favor of that is also more dispersed authority in organization, use of expert power to influence, using also informal rules and procedures, which results also in more informal cooperation between managers and other employees. Despite management behavior in Slovenia can be characterized as democratic, in comparison to Austria, this is not typical democratic behavior as suggested in the main stream literature (Kovač et al., 2004; Potocan, Mulej, 2007; Nedelko, 2011). Management in Slovenian organizations is rather often based on predispositions from previous system, which put in the forefront participation of all employees in management processes (Potocan, Mulej, 2007; Nedelko, 2011). Thus, nowadays this feature can be misleading when assessing state of management behavior among Slovenian managers.

Cognitions about association between managers' personal values and management behavior reveals that power is significantly associated with management behavior, indicating important role of power values in management behavior among Austrian managers. Furthermore, management behavior is thus built based on power values, which reflects typical characteristics of autocratic leadership style (Tannenbaum, Schimdt, 1973; Schermerhorn, 2008). Such state of management behavior in Austria is in line with typical characteristics of German speaking culture, emphasizing order, discipline, hierarchy, formality, position, authority and power (Brodbeck et al., 2000; Armbrüster, 2005; Tomalin, Nicks, 2010). 
In terms the impact of managers' personal values on their behavior in Slovenia, besides power also benevolence plays an important role. Evident is that in practice benevolence, coupled with characteristic of previous specific management behavior, emphasize management behavior that put in the forefront participation of other employees in decision making and management processes and extensive collaboration between management and employees, coupled with informal communication.

Thus, having simultaneously important power and benevolence values, which inversely influence on management behavior, in Slovenia often in business practice means that power is concentrated in hands of few managers in organizations. While, at the same time inclusion of employees in decision making and management processes is very limited and very often only consultative nature when making decisions.

In terms of conceptual implications, this paper outlines the association between managers' personal values and management behavior, using concepts previously not used in combination. This paper has some practical implications as well. First, acquaintance with management behavior in two neighborhood countries which have strong trade, will help to better understand each other parties when conducting business. Second, knowing actual state of management behavior in Slovenia can help owners and managers in Slovenia to critically analyze their actual behavior and asses perceived gaps in management behavior, according to well-developed western economies. Third, knowing about prevalent management behavior in Slovenian organization, can serve as a guideline for organizations those want to enter on Slovenian market, in different types of enter (e.g. as strategic partners, joint ventures, acquisition, green or brown-field investments) when selecting management, defining policies and goals, etc.

Paper has some limitations. First, in terms of generalizability of findings based on Slovenian sample on all Former Yugoslavia Republics, a critical analysis should be done, due to the difference between Slovenia and rest of former Yugoslavia, in term of general development, ties with western economies, relatively autonomous position of Slovenia in former Yugoslavia, implementation of reforms already in former Yugoslavia. Second, based on examining only personal values and selected demographic and organizational variables we cannot certainly assume about roots of management behavior, despite great importance of personal values for management behavior.

In terms of future research some possible directions are: inclusion of more drivers of management behavior, expand numbers of items measuring management behavior, conduct research in other counties, like Germany or Poland.

\section{References}

1. Ardichvili, A., Gasparishvili, A. (2001). Sociocultural Values, Internal Work Culture and Leadership Styles in Four Post-communist Countries // International Journal of Cross Cultural Management. Vol. 1, No. 2, p. 227-242. doi: $10.1177 / 147059580112006$.
2. Ardichvili, A., Kuchinke, K. P. (2002). Leadership styles and cultural values among managers and subordinates: a comparative study of four countries of the former Soviet Union, German, and the US // Human Resource Development International. Vol. 5, No. 1, p. 99-117. doi: $10.1080 / 13678860110046225$. 
3. Armbrüster, T. (2005). Management and Organization in Germany. - Hampshire: Ashgate Publishing Limited.

4. Aslund, A. (1994). Comment on "macropolicies in transition to market economy: A three-year perspective", by Balcerowicz and Gelb. - World Bank Research Observer, Annual conference supplement.

5. Bass, B. M., Avolio, B. J. (1990). Transformational Leadership Development: Manual for the Multifactor Leadership Questionnaire. - Palo Alto, CA: Consulting Psychologists.

6. rodbeck, F. C., Frese, M., Akerblom, S., Audia, G., Bakacsi, G., Bendova, H., et al. (2000). Cultural variation of leadership prototypes across 22 European countries // Journal of Occupational and Organizational Psychology. Vol. 73, No. 1, p. 1-29. doi: 10.1348/096317900166859.

7. Burns, J. (1978). Leadership. - New York: Harper \& Row.

8. Campos, N. F., Coricelli, F. (2002). Growth in Transition: What We Know, What We Don't and What We Should // Journal of Economic literature. Vol. 40, No. 3, p. 793-836. URL: http:// www.jstor.org/stable/3217110.

9. Černe, F. (1989). Jugoslovansko samoupravno gospodarstvo: v teorijo in praksi. - Ljubljana: Gospodarski vestnik.

10. Certo, S. C., Certo, S. T. (2009). Modern Management: Concepts and Skills. - New Jersey, Upper Saddle River: Pearson Education.

11. Connor, P. E., Becker, B. W. (1994). Personal values and management: what do we know and why don't we know more? // Journal of Management Inquiry. Vol. 3, No. 1, p. 67-73. doi: $10.1177 / 105649269431011$.

12. Daft, R. L. (2000). Management. - Fort Worth: The Dryden Press.

13. De Melo, M., Denizer, C., Gelb, A. (1996). From Plan to Market: Patterns of Transition. - Washington DC: World Bank.

14. Djankov, S., Murrell, P. (2002). Enterprise Restructuringin Transition:A QuantitativeSurvey// Journal of Economic Literature. Vol. 40, No. 3, p. 739-792. doi: 10.1257/002205102760273788.

15. Egri, C. P., Herman, S. (2000). Leadership in the North American Environmental Sector: Values, Leadership Styles, and Contexts of Environmental Leaders and their Organizations // The Academy of Management Journal. Vol. 43, No. 4, p. 571-604. doi: 10.2307/1556356.

16. England, G. W. (1967). Personal value systems of American managers // Academy of Man- agement Journal. Vol. 10, No. 1, p. 53-68. doi: $10.2307 / 255244$.

17. England, G. W. (1976). The manager and his values: An international perspective from the United States, Japan, Korea, India, and Australia. Cambridge: Ballinger.

18. Ericson, R. E. (1991). The Classical Soviet-Type Economy: Nature of the System and Implications for Reform // Journal of Economics Perspectives. Vol. 5, No. 4, p. 11-27. doi: 10.1257/jep.5.4.11.

19. Finkelstein, S., Hambrick, D. C. (1996). Strategic leadership: Top Executives and their effects on organization. - New York: West Publishing Company.

20. Fischer, S., Gelb, A. (1991). The Process of Socialist Economic Transformation // The Journal of Economic Perspectives. Vol. 5, No. 4, p. 91105. doi: 10.1257/jep.5.4.91.

21. Giberson, T. R., Resick, C. J., Dickson, M. W., Mitchelson, J. K., Randall, K. R., Clark, M. A. (2009). Leadership and Organizational Culture: Linking CEO Characteristics to Cultural Values // Journal of Business Psychology. Vol. 24, No. 2, p. 123-137. doi: 10.1007/s10869-0099109-1.

22. Hage, J., Dewar, R. (1973). Elite values versus organizational structure in predicting innovation // Administrative Science Quarterly. Vol. 18, No. 3, pp. 279-290. URL: http://www. eric.ed.gov/ERICWebPortal/search/detailmini. jsp?_nfpb=true\&_\&ERICExtSearch_Sea rchValue_0=EJ085999\&ERICExtSearch_ SearchType_0=no\&accno=EJ085999.

23. Hambrick, D. C., Mason, P. A. (1984). Upper echelons: The organization as a reflection of its top managers // Academy of Management Review. Vol. 9, No. 2, p. 193-206. doi: 10.2307/258434.

24. Harvie, C. (1999). Economic transition: what can belearned from China's experience//International Journal of Social Economics. Vol. 26, No. 7-9, p. 1091-1119. doi: 10.1108/03068299910245840.

25. Hofstede, G. (1980). Cultures Consequences: International/Differences of Work-Related Values. - Beverly Hills: Sage.

26. Hood, J. N. (2003). The Relationship of Leadership Style and CEO Values to Ethical Practices in Organizations // Journal of Business Ethics. Vol. 43, No. 4, p. 263-273. doi: 10.1023/ a: 1023085713600 .

27. House, R. J., Hanges, P. J., Javidan, M., Dorfman, P. W, Gupta, V. (2004). Culture, leadership, and organizations: The GLOBE study of 62 societies. - Thousand Oaks: Sage. 
28. Hughes, R. L., Ginnett, R. C., Curphy, G. J. (2009). Leadership: Enhancing the Lessons of Experiences. - Boston: McGraw-Hill/Irwin.

29. Kornai, J. (1992). The Socialist System: The Political Economy of Communism. - New Jersey: Princeton University Press.

30. Kovač, J, Mayer, J., Jesenko, M. (2004). Stili in značilnosti uspešnega vodenja. - Kranj: Moderna organizacija.

31. Kozminski, A. (2008). Anatomy of systemic change in polish management in transition // Communist and Post-Communist Studies. Vol. 41, No. 3, pp. 263-280. doi: 10.1016/j. postcomstud.2008.06.006.

32. Lang, R., Kovač, J., Bernik, M. (2000). Management v tranzicijskih procesih. - Kranj: Moderna organizacija.

33. Marangos, J. (2005). Alternative paths to the transition process // International Journal of Social Economics. Vol. 32, No. 4, p. 307-324. doi: 10.1108/03068290510587033.

34. Marx, K., Engles, F. (2008). Komunistični manifest. - Ljubljana: Maks Viktor.

35. McEwan, T. (2001). Managing Values and Beliefs in Organizations. - Harlow: Financial Times/ Prentice Hall.

36. Megginson, L. C., Mosley, D. C., Pietri, P. H. Jr. (1992). Management: Concepts and Applications. - New York: HarperCollins Publishers.

37. Mrak, M., Rojec, M., Silva-Jauregui, C. (ed.). (2004). Slovenia: From Yugoslavia to the European Union. - Washington: The World Bank.

38. Nedelko, Z. (2011). How to innovate managerial values. - Maribor: EPF.

39. Nedelko, Z., Mayrhofer, W. (2012). The influence of managerial personal values on leadership style. - Paper presented at $11^{\text {th }}$ World Congress of the IFSAM, Limerick, June 26-29.

40. Newman, K., Nollen, S. (1998). Managing Radical Organizational Change: Company Transformation in Emerging Market Economies. - London: Sage Publications.

41. Peng, M. W., Heath, P. S. (1996). The Growth of the Firm in Planned Economies in Transition: Institutions, Organizations, and Strategic Choice // The Academy of Management Review. Vol. 21, No. 2, p. 492-528. URL: www.jstor.org/ stable/258670.

42. Peters, T. J., Waterman, R. H. (1982). In Search of Excellence. - New York: Harper \& Row.

43. Posner, B. Z. (2010). Values and the American Manager: A Three-Decade Perspective // Jour- nal of Business Ethics. Vol. 91, No. 4, p. 457465.

44. Posner, B. Z., Munson, J. M. (1979). The importance of values in understanding organizational behavior // Human Resource Management. Vol. 18, No. 3, p. 9-14. doi: 10.1002/ hrm.3930180303.

45. Potocan, V., Mulej, M. (2007). Transition into innovative enterprise. - Maribor: EPF.

46. Ralston, D. A., Gustafson, D. J., Cheung, F. M., Terpstra, R. H. (1993). Differences in Managerial Values: Study of U.S., Hong Kong, and PRC Managers // Journal of International Business Studies. Vol. 24, No. 2, p. 249-275. doi: 10.1057/ palgrave.jibs.8490232.

47. Ralston, D. A., Pounder, J., Lo, C. W. H, Wong, Y. Y, Egri, C. P., Stauffer, J. (2006). Stability and Change in Managerial Work Values: A longitudinal Study of China, Hong Kong and the USA // Management and Organization Review. Vol. 2, No. 1, p. 67-94. doi: 10.1111/j.1740-8784.2006.00031.x.

48. Ralston, D. A., Egri, C. P., Reynaud, E., Srinivasan, N., Furrer, O., Brock, D., et al. (2011). A twenty-first century assessment of values across the global workforce // Journal of Business Ethics. Vol. 104, No. 1, p. 1-31. doi: 10.1007/ s10551-011-0835-8.

49. Reynaud, E., Egri, C. P., Ralston, D. A., Danis, W., Starkus, A., Dabic, M., et al. (2007). The Differences in Values Between Managers of the European Founding Countries, the New Members and the Applicant Countries: Societal Orientation or Financial Orientation? // European Management Journal. Vol. 25, No. 2, p. 132-145. doi: 10.1111/j.1740-8784.2006.00031.x.

50. Rokeach, M. (1973). The nature of human values. - New York: The Free Press.

51. Sarros, J. C., Santora, J. C. (2001). Leaders and values: a cross-cultural study // Leadership \& Organization Development Journal. Vol. 22, No. 5, p. 243-248. doi: 10.1108/01437730110397310.

52. Schermerhorn, J. R. (2008). Management. - New Jersey: John Wiley \& Sons.

53. Schwartz, S. H. (1992). Universals in the content and structure of values: Theoretical advances and empirical tests in 20 countries / In Advances in experimental social psychology, ed. M. P. Zanna. - Orlando: Academic Press.

54. Sosik, J. J. (2005). The role of personal values in the charismatic leadership of corporate managers: A model and preliminary field study // The Leadership Quarterly. Vol. 16, No. 2, p. 221-244. doi: 10.1016/j.leaqua.2005.01.002. 
55. Tannenbaum, R., Schmidt, W. (1973). How to Choose a Leadership Style // Harvard Business Review. Vol. 51, No. 3, p. 58-67. URL: http://hbr. org/1973/05/how-to-choose-a-leadership-pattern.

56. Tomalin, B., Nicks, M. (2010). The World's business cultures and how to unlock them. - London: Thorogood Publishing.

57. Uhlenbruck, K., Meyer, K., Hitt, M. (2003). Organizational Transformation in Transition
Economies: Resource-based and Organizational Learning Perspectives // Journal of Management Studies. Vol. 40, No. 2, p. 257-282. doi: 10.1111/1467-6486.00340.

58. Zahra, S. A, Ireland, D. R., Gutierrez, I., Hitt, M. A. (2000). Privatization and Entrepreneurial Transformation: Emerging Issues and a Future Research Agenda // The Academy of Management Review. Vol. 25, No. 3, p. 509-524. URL: www.jstor.org/stable/259307.

The paper submitted: May 15, 2013

Prepared for publication: June 28, 2013

Zlatko NEDELKO

\section{VADOVU ASMENINIỤ VERTYBIỤ POVEIKIS JỤ ELGSENAI: AUSTRIJOS IR SLOVÉNIJOS ATVEJIS}

\section{S a n tra u k a}

Pagrindinis šio straipsnio tikslas - išnagrinèti vadovų asmeninių vertybių įtaką jų elgesiui dvejose kaimyninèse šalyse - Austrijoje ir Slovėnijoje. Austrija turi gilias laisvosios rinkos ekonomikos tradicijas, tuo tarpu Slovenija - neseniai perejimo laikotarpi išgyvenusi šalis. Slovėnija turèjo tam tikros rūšies socializmo - „savarankiškos vadybos“, kurios pagrindinè ideja buvo atiduoti įmones darbuotojams. Tai reiškia, jog organizacijos buvo valdomos jų pačių darbuotojų. Slovenija baigè savo perejimą, kadangi organizaciniu lygmeniu pagrindinis atviras klausimas yra susijęs su valdymo elgesio perejjimu. Dèl unikalaus valdymo elgesio buvusioje sistemoje, kartu su paplitusia kolektyvistine vertybine orientacija, vadovų asmeninių vertybių ir dabartinio Slovènijos valdymo elgesio nagrinèjimas yra aktualus.

Be to, atliktas lyginamasis tyrimas su šalimi, turinčia istoriškai reikšmingą, skirtingą vystymosi kelią ir skirtingas vyraujančias kultūrines ir vertybines orientacijas yra vertingas. Tai padeda nustatyti asmeninių vertybių poveikị ir jų galimą palikimą iš ankstesnès, kolektyvistinès vertybinès orientacijos, valdymo elgesiui Slovėnijoje, kaip neseniai perèjimo laikotarpị išgyvenusioje šalyje.

Asmeninès vertybès straipsnyje yra matuojamos naudojant visą sąrašą asmeninių vertybių iš Schwartz vertybių tyrimo, tuo tarpu valdymo elgesys - naudojant tipines valdymo elgesio charakteristikas. Asmeninių vertybių ittaka valdymo elgesiui yra kontroliuojama demografiniais kintamaisiais. Imtis sudaro 208 vadovus iš Slovènijos ir 196 vadovus iš Austrijos organizacijų.

Asmeninių vertybių vaidmuo ir svarba vadybos literatūroje yra gana plačiai analizuojama, kadangi joje dominuoja atlikti tyrimai iš gerai išsivysčiusių šalių, turinčių senas laisvosios rinkos ekonomikos tradicijas. Centrineje ir Rytų Europoje ši tema daugiausiai nagrinèta šalyse, kurioms anksčiau buvo būdinga socialistinè sistema - buvusioje Sovietų Sajungoje, Lenkijoje. Be to, ši tema buvo mažiau nagrinèta šalyse, kuriose vyravo unikali socializmo sistema, pvz. Jugoslavijoje ir vėlesnèse jos apskrityse.

Pagrindinis atlikto tyrimo indèlis mokslinei literatūrai, yra išsamus asmeninių vertybių įtakos valdymo elgesiui palyginimas vokiškai šnekančioje, laisvosios rinkos su senomis tradicijomis ekonomikoje - Austrijoje; bei neseniai perejjimo laikotarpi išgyvenusioje šalyje, kurioje istoriškai vyravo labai specifinė kolektyvistinè sistema - Slovénijoje. Iki šiol mokslinèje literatūroje tai nebuvo analizuota.

Kalbant apie konceptualias išvadas, straipsnyje išryškinamos asociacijos tarp vadovų asmeninių vertybių ir valdymo elgesio naudojant koncepcijas, kurių deriniai prieš tai nebuvo naudoti. Tyrimo rezultatai skelbia praktinę atlikto tyrimo naudą. Pirma, pažinimas galètų pasitarnauti siekiant geriau suprasti valdymo elgesị dvejose kaimyninėse šalyse, kuriose yra stipri prekyba. Antra, tikrosios valdymo elgesio situacijos Slovènijoje žinojimas, gali padèti verslų savininkams bei vadovams kritiškai analizuoti jų faktinị elgesị bei sudaryti pagrindą plano, siekiant koreguoti ar pertvarkyti valdymo elgesi, sukūrimui ir vystymui. Trečia, paplitusio valdymo elgesio Slovėnijos organizacijose žinojimas, gali padèti organizacijoms pasirinkti ịejimo i Slovénijos rinką būdus (pvz. kaip strateginiai partneriai, bendros įmonès įsigyjimas), renkantis valdymo būdus, apsibrèžiant politiką, tikslus ir pan. 